\title{
Why is Dialectical Materialism the People's World Outlook and Methodology of the Communist Party of China?
}

\author{
Jiayue Quan ${ }^{1}$ \\ ${ }^{1}$ College of Marxism, Northwestern Polytechnical University, Xi'an, China \\ Correspondence: Jiayue Quan, College of Marxism, Northwestern Polytechnical University, Xi'an, China. Tel: \\ 153-1993-8761. E-mail: quanjiayue710062@126.com
}

Received: January 17, 2019

Accepted: February 19, 2019

Online Published: February 28, 2019

doi:10.5539/jpl.v12n1p128

URL: https://doi.org/10.5539/jpl.v12n1p128

The research is financed by (Sponsoring information) the ministry of education of youth fund project in 2019 (Title: "Advance together " and the early spread of Marxism in China).

\begin{abstract}
Dialectical materialism is the scientific worldview to combinine the materialism and dialectics Organically. Dialectical materialism is the people's world outlook and methodology of the communist party of China. Insisting on the dialectical materialism must proceed from reality; must be positive to face and resolve contradictions encountered in advance; must constantly enhance the dialectical thinking ability; must push forward the theories innovation based on practice.

\section{Introduction}

Dialectical materialism and historical materialism is the most fundamental characteristics of Marxist theory, is also the theoretical cornerstone of Marxism party. Xi jinping in the conference of celebrating the 40th anniversary of the reform and opening stressed that "we must insist on the dialectical materialism and historical materialism world outlook and methodology, correctly dealing with the relation between reform, development and stability." On January 23, $2015 \mathrm{Xi}$ jinping delivered an important speech: "dialectical materialism is a man's world outlook and methodology of the communist party of China". This paper expounds the connotation and significance of dialectical materialism and dialectical materialism systematically and explicitly put forward the member and the Leading cadres of the Communist Party of China to be a model to master and use the materialism.
\end{abstract}

\section{View}

Xi jinping pointed out, "dialectical materialism is a man's world outlook and methodology of the Communist Party of China". The deep judgment scientifically reveals the theory and practice of dialectical materialism, and illuminates the basic requirement of the communist party of China people. It is to enrich and develop Marxism epistemology and the theory of party building.

\subsection{What Is a Dialectical Materialism?}

Dialectical materialism is a scientific worldview to combinine materialism and dialectics Organically. In the paper of "the speech In Marx's the tomb", Engels put Marx's great contribution summed up in two big discovery: Historical materialism (the law of development of human history) and the theory of surplus value (the special motion law of modern capitalism). Marx had applied the dialectical materialist doctrine in the field of social and historical development, creatively revealed the development law of human society, the historical materialism, which is also called historical materialism.

\subsection{Why does the Communist Party of China insist on the dialectical Materialism?}

Insisting on the dialectical materialism is the basic requirement for the communist party of China. Why dialectical materialism is the world outlook and methodology of the Communist Party of China? Fundamentally speaking, it is based on the Marxism party of its own nature and deep understanding of Marxist theory. Worldview is the general view and basic view of people of the whole world as well as the relationship between man and the world. The worldview is the most basic, most important; it determines a person's outlook on life and values. From the philosophical point of view, it reflects everyone needs to face three major contradictions: the 
contradiction between man and nature (worldview), the contradiction between people and society (values), the people's psychosomatic contradiction (philosophy). How to solve the contradiction between man and nature? Humanity is to survive, first through labor, through the practice to solve the contradiction between man and nature, and is formed in the process of the view of the world is the world outlook. The unity of the world outlook, the outlook on life and values is idea foundation and behavior patterns of the source of ideology that everyone thinks everything. Marxist dialectical materialism and historical materialism are scientific world outlook and methodology, which opposed to idealism. It emphasizes to respect the nature, human and social development, on the basis of objective laws, to give full play to people's subjective initiative. And emphasizes that the people are the subject of history activity; is the creator of social material wealth and spiritual wealth; is the decision of the social change. Therefore, Marxist dialectical materialism is into people's world outlook and methodology of the Communist Party of China, as the guiding ideology of the Communist Party of China. This worldview also determines that the fundamental values of Marxism party can only be "by the people as the center", and the Communist Party of China people's values must also can only be " to serve the people by heart and soul." Therefore, insisting on the dialectical materialism is the basic requirement for the communist party of China.

Insisting on the dialectical materialism is based on the summary of historical practice for China. The communist party of China in the long-term revolution, construction and reform practice, use of the dialectical materialism in flexible to have a original theory achievements and great achievement. During the period of revolution and construction, MAO Zedong had written down works such as "the opposition bookishness", "the theory of practice"," the theory of contradiction", "discussion on ten relationship", "on the correct handling of contradictions among the people". It is called "a shining example of a master and apply dialectical materialism" by Xi Jinping. Deng Xiaoping is also very good at using dialectical materialism to solve practical problems. He stressed such as "taking economic construction as the center", "three benefits standard, "to combine, both hands to hard", "touch stone across the river", "deal with good plan and market, the actual and wealth together etc.". Xi Jiping stressed that if not dialectical materialism and historical materialism view of the world in mind, cannot be in the correct position and scientific attitude to understand the complicated objective things to grasp the law of development of things.

Insisting on the dialectical materialism is based on deep insight into the trend of The Times. Xi jinping pointed out that the Communist Party of China should unite to lead the people to realize "two one hundred" goal, he Must insist on more consciously and to use the dialectical materialism world outlook and methodology, Only better in practice to grasp the phenomenon and the essence, form and content, reason, and as a result, the relationship between internal cause and external cause, to enhance the capacity of dialectical thinking, strategic thinking, to have done the work better.

\subsection{How to Insist on the Dialectical Materialism?}

Proceed from objective reality. Everything from objective reality is the inevitable requirement and logical conclusion to adhere to the unity of material world. Xi jinping pointed out that China's largest actual is in and will be in the primary stage of socialism for a long time. This is the objective basis points that We know the present, planning for the future, making policy, promoting enterprise development. If out of this, will make mistakes, even subversive mistake. The reality is not static but changes constantly. The connotation of China's national conditions will change constantly; the international risk and the challenges faced by the major change will occur; new contradiction will also continue to produce. It requests us dialectical analysis of the different development phases, accurately grasping the new changes in the new characteristics of different stages, making subjective better conform to the objective.

At the same time, xi jinping stressed that dialectical materialism emphasizes the unity of the world lies in its material, but do not deny that consciousness to the adverse effects of the material, but sometimes this kind of reaction is very big. So, we emphasize the ideal faith education, ideological and moral construction, the ideological work, cultivate and carry forward the socialist core values, with the spirit of the Chinese rich period flavor to condense power in China. The Communist Party of China emphasizes the ideal faith is the communist's spiritual "calcium", emphasize "revolutionary ideals than day". This is the dialectics of spirit into material, material into spirit.

Positive to face and resolve contradictions encountered in advance. If you turn a blind eye to contradiction, even avoidance, hide contradictions, hang back in front of contradictions, sit see contradictions malignant transformation, finally certainly will cause irreparable damage. Mastering the basic principle of the contradiction movement of things requires us to constantly enhance the consciousness of the problem, problem oriented, positive face new contradictions in the process of solving the conflict of the old problems. Positive to face and 
solve contradictions, but also pay attention to grasp the primary and the secondary contradictions, the main aspects and the secondary aspects. In any job, we should not only speak two, but also to emphasize the point. Since the 18th National Congress of the Communist Party of China (CPC), proposed to coordinate to comprehensively build a well-off society, comprehensively deepen reform, comprehensively governing the country according to law, comprehensively strictly self-governance of the Communist Party of China. In the process, should not only pay attention to the overall planning, but pay attention to grasp key again.

Increasing the dialectical thinking ability. Xi jinping profoundly pointed out that the further development of the more, the more to enhance the dialectical thinking ability. Adhere to and use of materialist dialectics, must oppose subjectivism, formalism, mechanical, dogmatism and empiricism, metaphysical way of thinking. Only metaphysics Saves energy in the world, because it can talk nonsense, do not need to be on the basis of objective reality, also from the objective reality check. On the one hand, it is necessary to strengthen the investigation and study, to accurately grasp the objective reality, and really master law. On the other hand, must adhere to development rather than a single isolated observation of things, to properly handle the various significant relationships. Xi jinping stressed in the reform, we should give full consideration to the interests of different areas, different industries, different groups, to accurately grasp the intersection and integration of their interests and make reform efforts more fair benefit all the people.

Promote the theoretical innovation based on practice. Practice is the core of Marxist philosophy view. Practice is the source and power of knowing, but also the purpose and end result of knowing. There is no limit to practice, and theoretical innovation is no end. Xi jinping discusses the dialectical relationship between theory and practice. Once theory breaks away from practice, you will become a rigid dogma; will lose its vigor and vitality. There is no correct theory to guide practice, also easy to " a blind man rides a blind horse". The Communist Party of China has always attached great importance to theoretical work, emphasizing the theory must be united with practice. Theory reveals the laws deeper; leading role is more significant to the social development and change. Therefore, we should attach great importance to the role of theory, and attaché great importance to the theory of confidence and strategic concentration. According to The Times change, constantly bring forth theoretical innovation to realize the innovation in theory and practice of the benign interaction and promote Marxism in China In the unity and interaction.

\section{Conclusion}

Dialectical materialism and historical materialism reveal the essence of things, the inner link and law of development, is the understanding of the "great tool", and is a powerful ideological weapon that people see the world to analyze the problems. The communist party of China has been sticking to dialectical materialism, strengthening macro thinking and top-level design, adhering to the problem oriented, focusing on the outstanding contradictions and problems in the development. It is because the people of the Communist Party of China always adhere to the dialectical materialism and historical materialism; correctly handle the relationship between reform, development and stability, thus ensuring the reform process productively.

\section{References}

Big important literature compilation of (in) since the eighteenth, central literature publishing house, Beijing, in China, 2017.

Dialectical Materialism is the people's World Outlook and Methodology of the Communist Party of China, Xi Jinping, Seeking truth from facts, Beijing, in China, 2019.

Thirty speak of Xi Jinping's New Age of Socialism With Chinese Characteristics, Learning publishing house, Beijing, in China, 2018.

Xi Jinping talk about governing, volume 2. Foreign languages publishing house, Beijing, in China, 2017.

Xi Jinping: "redefining a well-off society in an all-round way and seize the new era of the great victory of socialism with Chinese characteristics", People's publishing house, Beijing, in China, 2017.

\section{Copyrights}

Copyright for this article is retained by the author(s), with first publication rights granted to the journal.

This is an open-access article distributed under the terms and conditions of the Creative Commons Attribution license (http://creativecommons.org/licenses/by/4.0/). 